\title{
A Research on the Performance and Characteristics of the Firms in Turkish Manufacturing Industry
}

\author{
Buhari DOGAN $^{*}$, Mesut ALBENI $^{* *}$, Vedat BAYDAR $^{* * *}$, Omer AKCAYIR ${ }^{* * * *}$
}

\begin{abstract}
This study aims to determine the factors affecting the performance of companies operating in the Turkish manufacturing industry. The sample of the study consists of 25394 firms which have been active in Turkish manufacturing industry between the years 2005 and 2011. Heckman sample selection model is used for the assessment of the growth and survival probabilities of the firms. According to the research model, it was found that the factors affecting firm performance are firm and industry based factors. It is concluded that Innovation, $R \& D$, export and branch variables have positive significant effects on the performance of the manufacturing industry firms.
\end{abstract}

Keywords: Firm Performance, Turkish Manufacturing Industry, Heckman Sample Selection Model

JEL Code Classification: D22, L25, 260

UDC: $338.45(560): 658.15$

DOI: https://doi.org/10.17015/ejbe.2016.017.05

\footnotetext{
*Ph.D, Department of Economics, Suleyman Demirel University. E-mail: buharidogan@sdu.edu.tr

** Professor, Department of Economics, Suleyman Demirel University. E-mail: mesutalbeni@sdu.edu.tr

${ }^{* * *}$ Research Assistant, Department of Econometrics, Suleyman Demirel University.

E-mail: vedatbaydar@sdu.edu.tr

${ }^{* * * *}$ Lecturer, Ph.D, Keciborlu Vocational School, Suleyman Demirel University. E-mail:

omerakcayir@sdu.edu.tr
}

Copyright (C, 2016 International Ataturk Alatoo University. 


\section{Introduction}

Firm performance has an important place in financial environment. Firm performance is the value which is produced as a result of a certain activity. Each firm is established in order to fulfill specific purposes. When all of the factors are used effectively, the produced value gets bigger than the expected value and thus firms can survive longer. Dynamic and competitive markets must improve their performance in order to increase profits and market value of the company. Thus, since the mid-80 firms, they have felt the need to control the production process. In this aspect, firms became aware of that keeping up with continuously changing conditions is possible only by understanding firm performance, and they aimed for healthy growth (Taticchi et al., 2008:6).

Healthy establishment of the firms has a very important effect on firm survival and growth. In this respect, there are many factors that effect the survival and growth of the firm. With the positive developments of recent research techniques, empricial studies conducted in the field of determining the firm performance indicators are increasing thanks to the ease of sample selection or finding, development of econometric tools, and the availability of data.

Some empirical studies have dealt with firm based factors affecting survival and growth performance of the firms (Hymer \& Pashigian, 1962). Firm structure and its economic activities affect firm's success. Firm based factors include basic factors about the firms like specifications, size, age, export experience, financial sources, abilities, operational elements, location of establishment, production structure and strategies, its strengths and weaknesses, innovation trends, aims and targets etc.

Some other studies dealt with especially entrepreneur and industry based factors. Entrepreneur based factors include demographic specifications of firm managers and decision makers and human capital. Entrepreneur's human capital is a good guide for a possible success. Factors derived from industry involve industry features such as industry entry barriers and industry competition level. On the other hand, environmental and macro based factors include macro-economic conditions or market development stages, and additionally external factors outside the control of the firm. According to the studies, firm survival and growth performance are related to firm, entrepreneur and industry based factors. Macro based factors are also related to firm survival and their growth performance. In this study, factors which determine the growth and the survival performance of the firms are discussed with the sample of Turkish manufacturing industry. Firstly, theoretical and empirical studies on factors affecting growth and survival performance of the firms are analysed. Then, the impact levels of factors affecting firm performance are studied by discussing the data set and implementation methodology. 


\section{Determinants of Firm Performance: Literature Review}

Firm specifications and economic activities are quite effective on firm success. In the literature, firm size and age are important variables, which determine the future performance of the firm according to the organizational ecology approach (Stinchcombe, 1965:142; Brüderl et al.1992:228). Firm size gives information about the establishment and subsequent life of the firm.

Firm size in the establishment phase has an important effect on firm's survival and growth performance. Firm size is measured by available capital at the time of establishment or by the number of employees; it can be measured by the turnover too. The most important issue about new firms is that they face with high death risk right immediately after entering the market and most of them can't survive (Dunne, Robert \& Samuelson, 1988:495). If the initial size of the firm is large, this increases the survival possibility of the firm; because firm decreases the costs which it will face later. The initial largeness of the firm will make it easier to use the existing scale economies and as a result of this, there won't be need for extra growth for survival (Audretsch, Santarelli \& Vivarelli, 1999:969).

It can be seen that there are both positive and negative studies on the effects of firm size regarding survival and growth performance. In some studies, it is approved that there is a positive relationship between initial firm size and survival (Audretsch \& Mahmood, 1995: 99; Mata et al. 1995: 470, Baptista \& Karaöz, 2006). But some other studies have results in contradictory directions (Caves, 2006; Audretsch et al. 1999; Agarwal \& Audretsch, 2001). For example, (Audretsch et al. 1999) couldn't determine this relationship for 9 out of 13 sectors in their study on Italian manufacturing industry. Karaöz and Albeni (2011) argued that firm size has no effect on firm survival in their TUBITAK study. In the same study, they found that there is a negative relationship between firm size and expected growth when focused on little firms. They emphasized that this is the possible reason for why there are so many small and micro sized firms in this sector.

Taking a look at the studies, which are focused at the small firms around the world, we see that they reached similar results.

For example Yasuda's (2005) study on Japanese manufacturing industry, Segarra and Callejon's (2002) study on Spanish manufacturing industry, McPherson's study (1996) on micro firms in South Africa, Wagner's (1992) and Almus and Nerlinger's studies (2000) on German manufacturing industry all release that there is a negative relationship between firm size and expected growth. This negative relationship can be explained with decrease of efficiency by size growth.

There are opinions, which suppose that both initial size and current size of the firms have to be dealed with in survival models. The relationship between firm size, survival and growth performance of the firms differs by regions and survival time. The reason for that is size does not give the same result for each region and firm. 
Likewise, the studies about firm size and performance, the relationship between firm age and firm performance are also a common subject for studies. Firm size and age are close consepts; they can represent the same basic thing in some situations (See Greiner model, 1972:37-46). There are numerous studies on this subject in different countries; therefore, it is possible to examine various studies about firm growth and survival performance.

Researches show that old firms make slower progress and they are less able to adapt to environmental changes. There is a common opinion that old firms don't have entrepreneur desire to see new business opportunities and bring these opportunities forward (Coad, 2009:84).

Researches show that compared to older firms younger firms have more advantage regarding the relationship between firm age and growth performance (Niskanen \& Niskanen, 2005). As the firms get older, production become monotonous. These firms countinue to do what they know best; they don't like changes and they fail to keep up with environmental changes. This situation causes recession for old firms in time. The recession may become deeper if the employees remain in the same position and resist change. However, young firms have appetite for success and growth, because they have entered the market recently. For this reason, they control the market better (Coad, 2009:84). As a result of this, younger firms act more willingly than old firms in terms of growth.

Evans (1987: 567-581) identified that there is a negative relationship between firm age and performance in his study conducted with 100 firms from different industries in the USA. In another study by Huynh and Petrunia (2009), it was found out that there is a negative relationship between firm age and growth performance in Canada. Yasuda (2005: 1-15) found that young firms show higher performance than older firms in his study about Japanese manufacturing industry (number of employees indexed). It was observed that firm age has negative effect on performance, but there are some studies which argue that it has positive effect on performance too.

Unlike these studies, in his study about manufacturing industry in Lakes Region (Göller Yöresi in Turkish), Demirgil (2008: 125-130) suggested that survival probability of the firms increases as the firms get older and firms use their experience as a continuity in their activities, therefore older firms are luckier than young firms.

In a study about 51 firms in computer industry in India, it was found that there is a positive relationship between firm age and performance (sales volume indexed) and large firms have lower growth ratios (Das, 1995:111-126). In another study which was again conducted in India with 392 manufacturing industries by Shanmugan and Bhaduri (2002:607), it was concluded that large firms have lower growth ratios and there is a positive effect between age and performance (sales volume indexed). 
Consequently, as mentioned in 'Life Stages' models, the relationship between firm age, growth and survival performance of the firms is not clear. The development level of the firm's country and size of the firm can be determinant in this situation. The positive effects of age factor can be seen with the firms which realized the necessarry change and transformation. The survival of the firms becomes harder if they can't realize the necessary change and transformation.

The ability to compete is becoming very important to adapt the complex and rapid changing environment. Firms have to follow special technologies and find a way to control the current technologies to gain competition advantage. Technology provides competetion advantage to manufacturing industries. This situation is accepted by academicians and governments which are the premium operators of technology (Kömürcü, 2008:36). Using technology provides high quality production, effective cost and quality service for the firms.

When we get to the base of the subject, it can be seen that firms are the basic source of innovation. Innovation affects firm performance in two ways. The first one is the increase in the number of employees and the other one is the increase in sales. The relationship between sales and innovation is complicated. Employment should be considered as labor input and sales should be considered as labor output. According to a study on this subject conducted by Carden (2005: 25), firm managers give great importance to innovation for growth. It was argued in Hay and Kamshad's study (1994:68) that the best innovation for the SMEs is product innovation.

Research and Development (R\&D) is another important activity for innovation. R\&D and technologic transformation are important for long term performance of the firms. It can be said that firms have major shortcomings about R\&D cooperation. It was observed that firms which cooperate with their competitors in R\&D are more successful in product and market innovation. In their study about the firms in manufacturing industry Ulusoy et al. (2008:13) concluded that firms which cooperate in R\&D are more innovative and have better firm performance. It was determined that large firms give more importance to cooperation, they make more investment on R\&D. For example, Rothaermel and Thursby (2005:1081) used R\&D and patent variables in their survival analysis on global technology firms and did not find a significant relationship between these two variables. In this context, patent variable has to be added with the R\&D variable to determine the survival and growth performance.

Many researches like Cockburn and Griliches (1988:420) and Hall (1993:610) proved that there is a significant positive relationship between R\&D costs and firm performance and market value. Sougiannis (1994:51) revealed that one dollar of increase in R\&D costs causes 2 dollars of increase in firm's earnings and it causes 5 dollars of increase in market value in next seven years. Deeds (2001) revealed that there is a positive relationship between R\&D density, technology development and technologic integration capability (Wang \& Chang, 2005:227). 
Based on these researches, it can be concluded that $R \& D$ expenditure affects not only current market value and performance but also firm's future performance (Seleim et al. 2004:345).

According to these studies, the survival and growth performance of the firms, which made difference by innovation, are higher than other firms. Innovative firms gain higher general performance compared to others.

There is a powerful relationship between a country's export and economic performance. Export is the most common way to enter international markets for the firms which aim to benefit from global market opportunities. With the globalization of the world economy, firms participate in international marketing activities by benefiting from international market opportunities both for obtaining a reliable market position and surviving in a high competitive environment (Yücel, 2006:1).

In the studies on this subject, it was observed that exporting firms are better than non-exporting firms in terms of efficiency, size and survival probabilities (Demirgil, 2008:20).

As the size of the firm increases, export potential rises too (Çavusgil \& Naor, 1987:222). Therefore, firm size affects the decisions of the firm managers whether or not to enter new export markets. The knowledge and experience of export managers about foreign markets are the driving force for internationalization efforts (Chetty, 1999: 122; O'Cass \& Craig, 2003: 369). For this reason, the increase of the experiences of the managers will lower the uncertainity about export activities and international markets, and it will contribute firms in terms of understanding foreign market mechanisms better. Besides, it will help managers develop their export experiences, personal communication abilities and customer relations network. Again, it will help to apply export-marketing programs (Katsikeas et al., 1996: 13-14; O'Cass \& Craig, 2003: 369). For this reason, export experiences of the managers affect firm survival and growth performance positively (Katsikeas et al. 1996: 13).

Penrose is the first strategic management theorist who revealed the relationship between entrepreneurship and firm resources. Penrose (1959: 11-49) argues that firms firstly have to recognize the efficiency opportunities and growth advantages. Catching these, opportunities depend on their desire and their reactions to these opportunities. According to Penrose, increase of the survival and growth performance of the firms, revealing the entrepreneurs' new ideas can be provided with the changes in product and technology (Jantunen, 2005).

Combining the firm based factors and entrepreneur-based factors strengthen the relationship between resources and performance. (Barney, 1995; Wiklund \& Shepherd, 2003). In their study, Covin and Slevin (1991) discussed entrepreneurship with conceptual model as a firm behaviour. They claim 
environmental / macro factors and firm based factors increase the firm performance by affecting firm's entrepreneur based factors.

Covin and Slevin (1991:18) think that firm resources and skills -strengthen the entrepreneural behaviour and performance of the firm by the role of conditional variable. According to these authors, the success of the product innovations is related to the success of marketing activities. Thus, the power of marketing activities increase the relationship between administrative factors and firm performance.

Researchers accept that firm owner or entrepreneur is a very important factor for survival and growth performance of the firm. Enrepreneural factors are important for explaining the success or failure of the entrepreneur. At this point, the experience of the firm owner and employees, social abilities, education, capabilities and skills are the basic factors affecting firm performance.

Human capital can be defined as the knowledge, ability, skill, experience, and education level of the firm owner or employees. Stewart (1994:94) accepts that human capital is the beginning of all stairs, the source of the invention and the fountain of the understanding. Human capital is important for the firms because it is the most effective factor for restructuring process, developing personal skills and exchanging ideas in research labs. Human capital is the sum of sources hidden in the entrepreneurs and the employees.

Initial environmental conditions are important for the firms newly entered to the industry. The operation and the level of the competitive environment differ in industries and affect firm performance. Firms change their behaviour and strategies according to different situations. On the other hand, the variables related to the industry life cycle take different values. In this context, the size of entry barriers to the industry is important for the firms which will enter to the market because the barriers will be different according to industry life cycle.

Macro based factors have an important place in determining firm performance. At the same time, initial environmental conditions affect firm performance. Studies try to explain country-specific components of firm performance. For instance, McPherson (1996:266) observed that the firms in South Africa have higher growth performance than other four African countries in his study. Although the changes of growth ratios of the firms are observed mostly between countries and industries (Geroski \& Gugler, 2004: 612), it is directive to consider the effects of macroeconomic factors on firm growth ratios while making assessments. There are numerous studies about how firm performance change in business cycle. Higson et al. (2002: 1544) examined 30 firms in the U.SA and England and found that average growth ratios of these firms are sensitive to macroeconomic waves. Also, higher momentums of growth ratios are sensitive to business cycle. Hardwick and Adams (2002: 579) researched the changes in the coefficent of the Gibrat law (coefficent $\beta$ ) and found the evidence of anti-cyclical change of this coefficent. This means that 
smaller firms grow faster when there is viability on the market. Big firms grow faster in decline and rescue periods.

Bayyurt and Duzu (2008: 81) compared manufacturing firms of two countries, China and Turkey, by using weight restricted data development method and they found that China is more efficient than Turkey in terms of processing its resources and creating outputs. They argue that manufacturing firms of Turkey have to increase their performance.

Mishra and Chandra (2010: 111) studied Indian pharmaceutical companies by using panel data analysis and they found out that size, selling efforts, import and export intensities of the firms affect the firm performance directly, and market share and demand affect the firm performance indirectly. They argue that mergers and acquisitions have no effects on firm performance. According to literature, firm performance can be explained as the combination of internal and external factors.

\section{The Development Process of Turkish Manufacturing Industry}

As a developing country, Turkey has important experience and potential in terms of industrialization. After 1930s, it is accepted that econonomic development is possible with only rapid industrialization in Turkey. But, "industrial based development" has been one of the basic aims of five-year development plans which have been applied since 1963. The main idea of this aim is the argument that manufacturing industry has an immersive role on economic growth (Arisoy, 2008: 11). There have not been any long-term action plan or approach for manufacturing industry. Even, there is not a specific target; manufacturing industry has shown important change in time as a result of policies and the experience of the industry.

The change of manufacturing industry share in total employement and GNP between 1970 and 2012 is shown in the figure 1. Its share in GNP rised from $15.7 \%$ to 27.1 . The share of manufacturing industry in total employement rised from $9.7 \%$ to $20.8 \%$ in 42 years. As seen in the figure, the values rised except the years 1979 and 1980 .

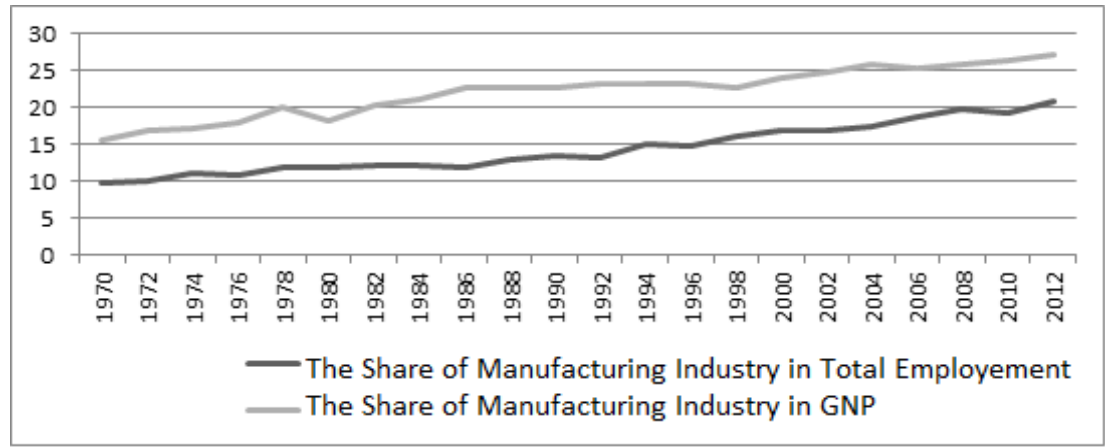

Figure 1: The Place of Manufacturing Industry in the Economy Source: TÜSiAD, (2008), Türkiye Sanayine Sektörel Bakış, TÜík, (2013), Türkiye İstatistik Yıllığı 
According to general business census which was made by TUIK in 2002, there are 1.720 .598 business ventures in Turkey. $14.35 \%$ of these ventures are in manufacturing industry. $40.09 \%$ of wage workers are in manufacturing industry. After 2002 general business census, the scope of business statistics was created based on the statistical classification of European Union economic activities. In 2001, the number of total business ventures in Turkey was 2.591 .082 . The share of manufacturing industry in total establishments was $12.86 \% .31 .66 \%$ of wage workers were in manufacturing industry (TÜiK, Türkiye İstatistik Yıllığı, 2013).

\section{Methodology}

In this study, the factors affecting firm growth and performance are studied. In this context, the data was obtained from TUIK micro database. STATA 11.0 Econometric analysis program was used for the Heckman Sample Selection Model.

\subsection{Data}

The sample of the study consists of the firms which have been active in Turkey Manufacturing Industry between the years 2005 and 2011. The population of the study consists of active manufacturing industry firms in 2002 business census. The sample of the study is 25.394 firms which were chosen randomly by TUIK in 2005 . 6.716 of these firms ended their activities in different times untill 2011.

\subsection{Analysis Methods}

There are econometric methodologies which claim that out of business firms have to be included to the analysis to find factors affecting firm performance. For this reason, there are studies which argue that both survival and growth depend on the same variables. While making performance analysis, out of business firms have to be included to the analysis instead of including only operating firms. Otherwise, it is thought that there will be sample selection problem and the estimates could $b$ e biased (Cragg, 1971; Heckman, 1979). So Heckman's (1979) sample selection model is used to overcome this problem.

Basic form of Heckman's (1979) sample selection model has two steps. At the first step, two variables $Z$ and $Y$ show whether variables are observed or not $(Y$ is observed if $Z=1$ ). At the second step, $Y^{\prime}$ 's expected value is modelled if it is observed. So, in the model there are $Z$ dummy, normally distributed latent variable $\left(Z^{*}\right)$ and the error term (e). If $Z=1$, the observation of $Y$ and the realization of the second latent variable $\left(\mathrm{Y}^{*}\right)$ take place with the error term $(\mathrm{u})$. It is assumed that the two error terms ( $u$ and e) are related and distributed normally. According to this Heckman model is as follows:

(i)

$$
\begin{aligned}
& \text { selection function (first step) } \\
& Z^{*}=W_{i}+e_{i} \\
& \text { If } Z^{*}=0 \text { then } Z_{i}=0 \\
& \text { If } Z^{*}>0 \text { then } Z_{i}=1
\end{aligned}
$$


(ii) output - growth equation (second step)

$$
\begin{aligned}
& Y^{*}=X_{i}+u_{i} \\
& \text { If } Z_{i}=1 \text { then } Y_{i}=Y^{*} \\
& \text { If } Z i=0, Y i \text { is not observed. }
\end{aligned}
$$

In the equations above, $\mathrm{Zi}$ is binary variable, $W_{i}$ and $X i$ are the vectors of the variables which include common components and intersection, ei and ui are the error terms. Two-step model has different calculations for growth and selection equations. It is assumed that error terms are distributed normally. $P$; shows the correlation between $\mathrm{e}_{i}$ and $\mathrm{u}_{i}$. If the correlation between $\mathrm{e}_{i}$ and $\mathrm{u}_{i}$ is zero, model can be estimated by two steps method (Cragg, 1971). If the correlation between $e_{i}$ and $u_{i}$ is equal to 1 , this means both the growth and the selection equations have the same process and they are sensitive to the same variables. In this case, two steps and Hecman models are downgraded to Tobit Model (Tobin, 1958).

$$
\begin{aligned}
& Y^{*}=X_{i}+u_{i} \\
& \text { If } Z_{i}=1 \text { then } Y_{i}=Y^{*} \\
& Z_{i}=0 ; \text { other situations }
\end{aligned}
$$

The equality of the coefficients are tested by LikelihoodRatio-LR Test, Tobit Model, Probit and Truncated regressions with ( $L R=-2[\ln L t-(\ln L p+\ln L t r)$. ( $L n L p$, is Probit likelihood ratio and LnLtr is Truncated regression likelihood ratio) (Greene, 2003). Significantly high LR values show that both selection and growth equations are sensitive to different exogen variables. In this case, two-steps model must be used instead of Tobit Model (Karaöz \& Albeni, 2011: 11). Also, if Inverse Mills Ratio is not equal to zero, sample selecton model have to be used.

\subsection{Descriptive Statistics}

16 variables are used for the analysis of the study. 2 dependent variables and 14 independent variables are used for firm growth and survival performance. Firm size, which is measured by the number of employees and turnovers, is used for performance analysis. Some of the variables are made cathegoric and others are continous variables.

The factors which are expected to be effective on growth and survival performance of the firms are about firm, industry and environmental/macro based factors. The variables of the study and descriptive statistics of them are shown in table 1.

\footnotetext{
* Inverse Mills Ratio shows if there is selection bias. If the coefficient is sitatistically significant there is selection bias. It can be said that there is not selection bias because we formulated the selection model. It is assumed that selection model is true. Inverse Mılls Ratio helps to find the effect on sale and employement. https://files.nyu.edu/mrg217/public/selection.pdf (26.12.2014)
} 
A Research on the Performance and Characteristics of the Firms in Turkish Manufacturing...

Table 1. Variables of the Analysis and Descriptive Statistics

\begin{tabular}{|c|c|c|c|c|c|c|}
\hline Variable & Dependent Variable & $\begin{array}{c}\text { Number of } \\
\text { Observations }\end{array}$ & Mean & $\begin{array}{c}\text { Std. } \\
\text { Deviation }\end{array}$ & Min. & Max. \\
\hline $\begin{array}{l}\text { Firm Growth } \\
\text { (LnGRWTH) }\end{array}$ & $\begin{array}{c}\text { The number of the } \\
\text { employees in } 2011 \text { - The } \\
\text { number of the } \\
\text { employees in } 2005\end{array}$ & 18678 & -35.681 & 396.56 & -1854 & 7625 \\
\hline $\begin{array}{l}\text { Survival } \\
\text { (Aktive) }\end{array}$ & $\begin{array}{l}\text { Active firms in } 2011 \text { 1, } \\
\text { out of business firms } 0\end{array}$ & 25394 & 0.7355 & 0.4413 & 0 & 1 \\
\hline Age (Fage) & $\begin{array}{l}2011 \text {-foundation year } \\
\text { of the firm if it is } \\
\text { operating, exiting year - } \\
\text { establishment year of } \\
\text { the firm if the firm is } \\
\text { out of business. }\end{array}$ & 25394 & 10.085 & 7.438 & 1 & 174 \\
\hline $\begin{array}{l}\text { Size } \\
\text { (Totalemp2005) }\end{array}$ & $\begin{array}{l}\text { The number of the } \\
\text { employees in } 2005\end{array}$ & 25394 & 100.16 & 332.12 & 1 & 7453 \\
\hline $\begin{array}{l}\text { Size } \\
\text { (Totalemp2011) }\end{array}$ & $\begin{array}{l}\text { The number of the } \\
\text { employees in } 2011\end{array}$ & 18678 & 58.788 & 215.79 & 1 & 7626 \\
\hline $\begin{array}{l}\text { Innovation } \\
\text { (Innovation) }\end{array}$ & $\begin{array}{l}\text { If firm innovates } 1 \text {, } \\
\text { otherwise } 0\end{array}$ & 25394 & 0.5791 & 0.4930 & 0 & 1 \\
\hline$R \& D(R \& D)$ & $\begin{array}{c}\text { If the firm makes } R \& D \\
1 \text {, otherwise } 0\end{array}$ & 25394 & 0.3782 & 0.4849 & 0 & 1 \\
\hline $\begin{array}{l}\text { Staff Payments } \\
\text { (InEmppay) }\end{array}$ & $\begin{array}{l}\text { The amount of firm's } \\
\text { payments to employees }\end{array}$ & 25394 & $1.79 e+08$ & $2.35 e+09$ & 0 & $7.45 e+10$ \\
\hline $\begin{array}{l}\text { Total Staff Costs } \\
\text { (InTotempcost) }\end{array}$ & Total cost of employees & 25394 & $2.38 \mathrm{e}+08$ & $2.99 e+09$ & 0 & $9.09 e+10$ \\
\hline Outsource & If the firm make & & & & & \\
\hline $\begin{array}{l}\text { Production } \\
\text { (Contractm) }\end{array}$ & $\begin{array}{c}\text { outsource production } 1, \\
\text { otherwwise } 0\end{array}$ & 25394 & 0.1386 & 0.3455 & 0 & 1 \\
\hline Stock (Stock) & $\begin{array}{l}\text { If the firm stocks } 1 \text {, } \\
\text { otherwise } 0\end{array}$ & 25394 & 0.1501 & 0.3571 & 0 & 1 \\
\hline $\begin{array}{l}\text { Investment } \\
\text { (Investment) }\end{array}$ & $\begin{array}{l}\text { The amount of firms' } \\
\text { investments }\end{array}$ & 25394 & $4.77 e+11$ & $1.60 \mathrm{e}+13$ & 0 & $1.21 \mathrm{e}+16$ \\
\hline Branch (Branch) & $\begin{array}{c}\text { If the firm has branches } \\
1 \text {, otherwise } 0\end{array}$ & 25394 & 0.7729 & 3.3377 & 0 & 178 \\
\hline Profit (Profit) & $\begin{array}{c}\text { Firm's profits from its } \\
\text { activities }\end{array}$ & 25394 & $5.56 e+07$ & $1.28 \mathrm{e}+09$ & 0 & $8.67 e+10$ \\
\hline Loss (Loss) & $\begin{array}{c}\text { Firm's loss from its } \\
\text { activities }\end{array}$ & 25394 & $9.70 \mathrm{e}+07$ & $1.78 \mathrm{e}+09$ & 0 & $9.49 e+10$ \\
\hline Export (Export) & $\begin{array}{l}\text { If the firm exports } 1 \text {, } \\
\text { otherwise } 0\end{array}$ & 25394 & 0.3769 & 0.4846 & 0 & 1 \\
\hline
\end{tabular}

\subsection{Empirical Model}

Equations were set for 3 models. The number of employees is used for growth function. Logarithmic values of variables are used for growth function equations. The dependent variable for the growth function is the number of employees and 
survival variable is used for selection equation. The variables of 2011 used for growth function and 2005 variables are used for selection function. Research model is the sample selection model which is used in the studies about firm growth.

Dependent variable $\mathrm{LNGRWTH}_{i}$ may not be always observed. For example, if the firm is in both 2005 and 2011, sample LNGRWTH ${ }_{i}$ can be observed for this firm. In other words this situation is true if the firm is active between (2005 and 2011). If the $i_{\text {th }}$ firm is in both 2005 and 2011 sample the variable Active ${ }_{i}$ will be equal to 1 ; if it is only in 2005 sample then the variable Active $e_{i}$ will be equal to 0 . $\omega_{i, t}$ is the error term of the selection function equation.

$$
\text { Aktif }_{i}=\left\{\begin{array}{l}
1 \\
\text { if } \begin{array}{l}
\text { Aktif }_{i}^{*}>0 \\
\text { Aktif }_{i}^{*} \leq 0
\end{array}
\end{array}\right.
$$

It is assumed that error terms $\left(\varepsilon_{\mathrm{i}-1}, \omega_{\mathrm{i}-1}\right)$ are distributed normally.

$$
\left(\begin{array}{c}
\varepsilon_{i-1} \\
\omega_{i-1}
\end{array}\right) \sim N\left(\left(\begin{array}{l}
0 \\
0
\end{array}\right)\left(\begin{array}{cc}
\sigma & \rho \sigma \\
\rho \sigma & 1
\end{array}\right)\right)
$$

Hence growth function can be defined as follows:

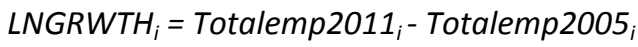

\section{Model 1}

Independent variables are, R\&D dummy (R\&D2011), innovation dummy (Innovation2011), payments to the employees (InEmppay2011), total employee cost (InTotempcost2011), outcast production from other firms (Contractm2011), firm stock dummy (Stock2011), firm profit (InProfit2011), firm loss (InLoss2011), firm investment (InInvestmnt2011), branches that show the firms' differentiation efforts (Branch2011), export dummy that shows the firms' trade strategies (Export2011), firm age $\left(F_{\text {age }}\right)$.

Estimation model for growth function is as follows:

$$
\begin{aligned}
& \text { LNGRWTH }_{i}=\alpha_{0}+\alpha_{1} R \& D 2011_{i, t}+\alpha_{2} \text { Innovation } 2011_{i, t}+ \\
& \alpha_{3} \text { lnEmppay2011 } 1_{i, t}+\alpha_{4} \text { lnTotempcost } 2011_{i, t}+ \\
& \alpha_{5} \text { Contractm } 2011_{i, t}+\alpha_{6} \text { Stock } 2011_{i, t}+\alpha_{7} \text { lnProfit } 2011_{i, t}+ \\
& \alpha_{8} \text { lnLoss } 2011_{i, t}+\alpha_{9} \text { lnInvestment } 2011_{i, t}+
\end{aligned}
$$

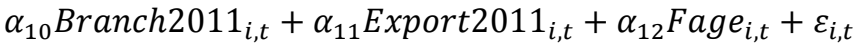

Independent variables are, R\&D dummy (R\&D2005), innovation dummy (Innovation2005), payments to the employees (InEmppay2005), total employee cost (InTotempcost 2005), outcast production from other firms (InContractm2005), firm stock dummy (Stock2005), firm profit (InProfit2005), firm loss (InLoss2005), firm investment (InInvestmnt2005), branches that show the firms' differentiation efforts (Branch2005), export dummy that shows the firms' trade strategies (Export2005) 
A Research on the Performance and Characteristics of the Firms in Turkish Manufacturing...

Estimation model for selection function is as follows:

$$
\begin{aligned}
& \text { Active }_{i}^{*}=\beta_{0}+\beta_{1} R \& D 2005_{i}+\beta_{2} \text { Innovation }_{i}+\beta_{3}{\text { InEmppay } 2005_{i}+}+
\end{aligned}
$$

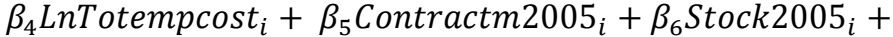

$$
\begin{aligned}
& \beta_{7} \text { lnProfit } 2005_{i}+\beta_{8} \text { lnLoss } 2005_{i}+\beta_{9} \text { lnInvestment } 2005_{i}+
\end{aligned}
$$

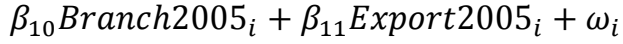

\section{Model 2}

Independent variables are, R\&D dummy (R\&D2011), innovation dummy (Innovation2011), outcast production from other firms (Contractm2011), firm stock dummy (Stock2011), firm profit (InProfit2011), firm loss (InLoss2011), firm investment (InInvestmnt2011), branches that show the firms' differentiation efforts (Branch2011), export dummy that shows the firms' trade strategies (Export2011), firm age $\left(F_{\text {age }}\right)$.

Estimation model for growth function is as follows:

$$
\begin{aligned}
& \text { LNGRWTH } H_{i}=\alpha_{0}+\alpha_{1} R \& D 2011_{i, t}+\alpha_{2} \text { Innovation } 2011_{i, t}+ \\
& \alpha_{3} \text { Contractm } 2011_{i, t}+\alpha_{4} \text { Stock } 2011_{i, t}+\alpha_{5} \ln \text { Profit } 2011_{\mathrm{i}, \mathrm{t}}+ \\
& \alpha_{6} \operatorname{lnLoss} 2011_{\mathrm{i}, \mathrm{t}}+\alpha_{7} \text { lnInvestment } 2011_{i}+\alpha_{8} \text { Branch2011 } 1_{\mathrm{i}}+ \\
& \alpha_{9} \text { Export2011 }_{\mathrm{i}}+\alpha_{10} \text { Fage }_{i}+\varepsilon_{i}
\end{aligned}
$$

Independent variables are, R\&D dummy (R\&D2005), innovation dummy (Innovation2005), outcast production from other firms (Contractm2005), firm stock dummy (Stock2005), firm profit (InProfit2005), firm loss (InLoss2005), firm investment (InInvestmnt2005), branches that show the firms' differentiation efforts (Branch2005), export dummy that shows the firms' trade strategies (Export2005)

Estimation model for selection function is as follows:

$$
\begin{aligned}
& \text { Active }_{i}^{*}=\beta_{0}+\beta_{1} R \& D 2005_{i}+\beta_{2} \text { Innovation }_{i}+\beta_{3}{\text { Contractm } 2005_{i}+}+
\end{aligned}
$$

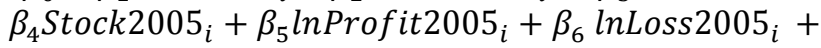

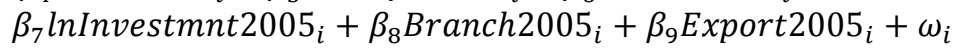

\section{Model 3}

Independent variables are, R\&D dummy (R\&D2011), innovation dummy (Innovation2011), firm stock dummy (Stock2011), ,firm profit (InProfit2011), firm loss (InLoss2011), firm investment (InInvestmnt2011), branches that show the firms' differentiation efforts (Branch2011), export dummy that shows the firms' trade strategies (Export2011), firm age $\left(F_{\text {age }}\right)$

Estimation model for growth function is as follows:

$$
\begin{aligned}
& \text { LNGRWTH } H_{i}=\alpha_{0}+\alpha_{1} R \& D 2011_{i}+\alpha_{2} \text { Innovation } 2011_{i}+ \\
& \alpha_{3} \text { InInvestment } 2011_{i}+\alpha_{4} \text { Stock } 2011_{i}+
\end{aligned}
$$

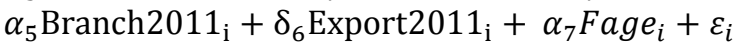

Independent variables are, R\&D dummy (R\&D2005), innovation dummy (Innovation2005), firm stock dummy (Stock2005), firm investment 
(InInvestmnt2005), branches that show the firms' differentiation efforts (Branch2005), export dummy that shows the firms' trade strategies (Export2005).

Estimation model for selection function is as follows:

$$
\begin{aligned}
& \text { Active }_{i}^{*}=\beta_{0}+\beta_{1} R \& D 2005_{i}+\beta_{2} \text { Innovation }_{i} 2005+\beta_{3}{\text { Stock } 2005_{i}+}+
\end{aligned}
$$

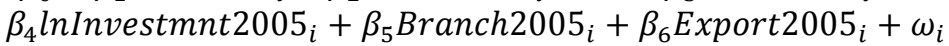

\section{Findings}

In this part of the study, the factors affecting manufacturing industry firms' performance are examined. Outputs which are obtained by using sample selection model are shared.

Correlation analysis is conducted among variables. Three different models are used because of the high correlation between the variables Emppay, Totempcost, Profit, Loss, and Contractm.

If we look at the significance of the variables Arge2011, Innovation2011, Branch2011, Export2011 are significant in growth function and Arge2005, Innovation2005, Branch2005, Export2005 are significant in selection function (see Table 2). Despite that, Investmnt2011, Investmnt2005, Stock2011, Stock2005 variables are not significant in all three models.

If the models on the table are analysed, it can be seen that Model 1 has the highest likelihood ratio. Model 1 is the most appropriate model with the value of 14306.18 compared to the other models.

Sample selection model outputs are shown in Table 2. Innovation and R\&D variables are statistically significant in growth and selection functions. Although innovation and R\&D are important for firm performance, they depend on the factors outside the firm. Growth and survival of innovative firms are easier. R\&D activities and innovative activities rise the performance of the firms and help to them develop the products.

The results of other studies are similar to this study. These results show that innovation and R\&D activities have significant effect on manufacturing industry firms.

According to the analysis results, it was concluded that firm age has a significant effect on firm performance. Performance increases with age and it depends on sustainable growth. The reason for that is young firms may reach saturation early with rapid and high growth rates. 
A Research on the Performance and Characteristics of the Firms in Turkish Manufacturing...

Table 2. Sample Selection Model of Factors Affecting Firm Performance

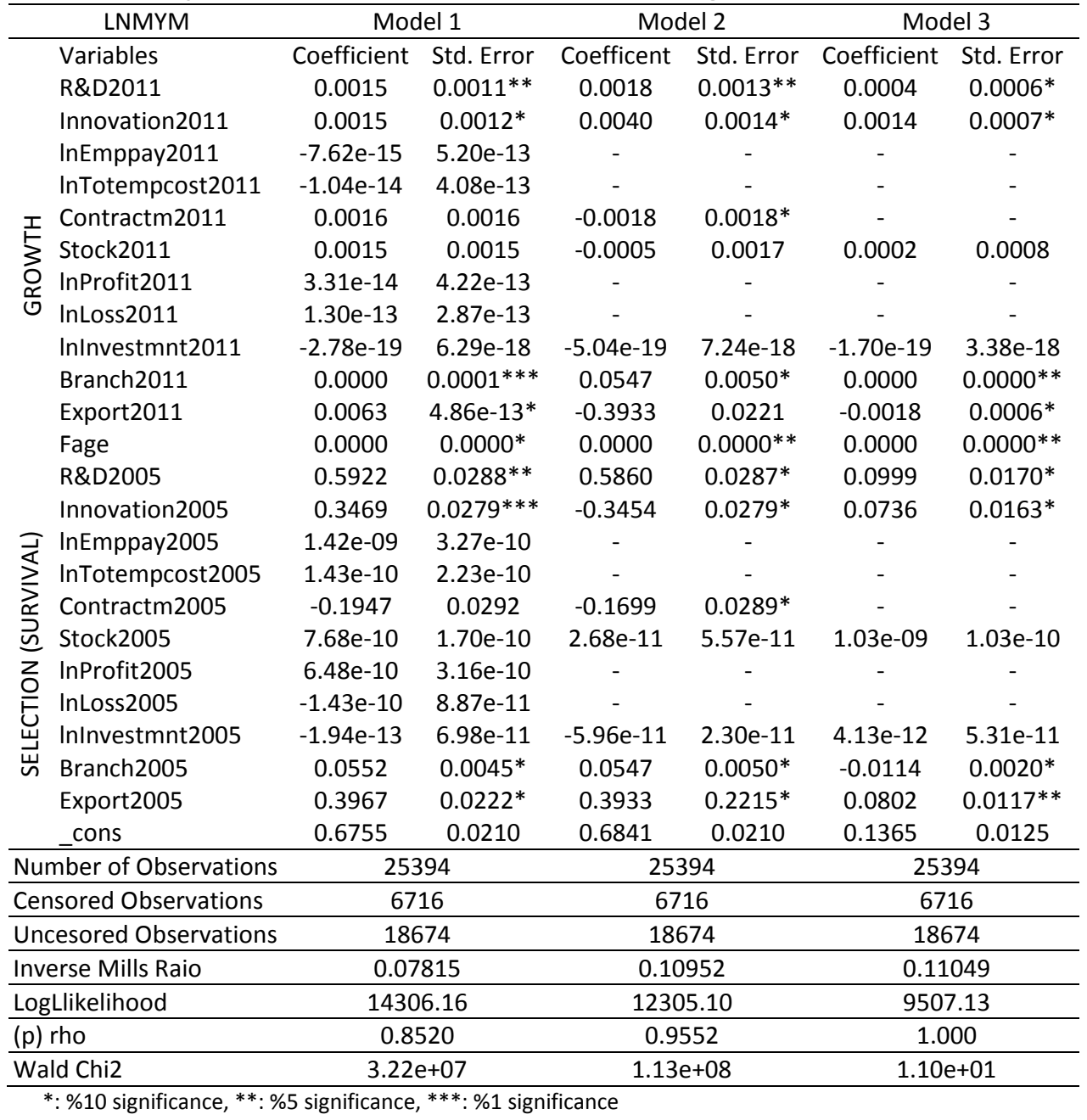

First of all, we see that firm's international activities by export have positive and statistically significant effect on growth performance. The increase of firm's export causes specialization in production of exportable products. This also increases efficiency. The literature shows that exporting firms have bigger size, they are more efficient, and they produce more capital and technology intensive products (Clerides et al., 1998; Aw et al., 1998; Bernard \& Jensen, 1999). According to the studies, the externalities and advantages of export affect firms' growth efforts positively (Robson \& Bennett, 2000; Freel \& Robson, 2004; Beck et al., 2005). There are two theoretical reasons which explain the performance increase of exporting firms. Firstly, exporting firrm takes advantage of scale economies by its activities in a big market. Secondly, the firms which are active in foreign markets are exposed 
to more intense competition, thus they have to be faster than the domestic firms (Wagner, 2002).

Branch variable is positive and significant in both models. It can be understood that well distributed firms have higher growth and survival performance. Branches help firms hold better to the market. Manufacturing industry firms which want to grow differ by opening branches. Despite these, outcast production, stock, profit-loss situations, payments to the employees, costs and investment activities of the manufacturing industry firms don't have significant effects on firm performance according to the analysis.

\section{Summary and Conclusions}

In this study, growth and survival performance of 25.394 manufacturing industry firms in Turkey between the years 2005 and 2011 are analysed. 18.678 of the sample are still active while 6.716 firms are not. There are countless factors affecting firm performance. The direction of these effects are researched in the study. It was concluded that factors affecting firm performance are firm and industry based factors.

It can be seen that Innovation, $R \& D$, export and branch variables have positive effects on the performance of the manufacturing industry firms. R\&D activities increase the firm profits. The increase in the profits are important for sustainibility of R\&D activities and firm survival and growth posibilities of the firms. So, investment on R\&D and innovation increase firm performance.

As seen in the results above, investment on innovation finances itself easily. Besides, innovation has other profits for the firms. To give an example, innovation provides competitive advantage, helps enterance to new markets and increase the profit and efficiency. It can be said that innovative firms are more successful than other firms in total sales, export, innovation, capital accumulation and profit rates.

The externalities gained by exporting affect firm performance positively. As the literature shows, exporting firms grow rapidly. Besides, having branches provide positive contribution to the firms and help them hold the market better.

The results of this study verifies the other results of studies such as Audretsch and Mahmood (1995), Baldwın and Johnson (1996), Cainelli et al., (2006), Becheikh et al.,(2006). These results are similar to the literature and they show that innovation, R\&D activities, export and branch variables are effective on firm growth and survival.

Based on these findings, it can be suggested that the first condition of survival is to adapt to the changing conditions. According to Peter Drucker, who is a management expert, if a constant firm can't innovate in this age, it faces failure (Drucker, 1985). In this context, firms of Turkish manufacturing industry have to adapt to today's market conditions for survival and growth. Firms have to give 
A Research on the Performance and Characteristics of the Firms in Turkish Manufacturing...

importance to R\&D, they have to be open to innovation, find new markets for export and be different by opening branches.

\section{References}

Agarwal, R., \& Audretsch, D.B. (2001). Does Start-up Size Matter?: The Impact of the Life Cycleand Technology on FirmSurvival. (Faculty WorkingPapers No.9808). University of Central Florida, College of Business and Administration.

Almus, M., \& Nerlinger, E.A. (2000). Testing "Gibrat's Law" for Young firms - Empirical Results for West Germany. Small Business Economics, 15, 1-12.

Audretsch, D.B., \& Mahmood T. (1995). New Firm Survival: New Result Using Hazard Function. Review of Economics and Statistics, 77, 97- 103.

Audretsch D.B., Santarelli, E., \& Vivarelli, M. (1999). Start-up Size and Industrial Dynamics: Some Evidence from Italian Manufacturing. International Journal of Industrial Organization, 17, 965-983.

Arisoy, I. (2008). Türkiye'de Sanayi Sektörü - İktisadi Büyüme illişkisinin Kaldor Hipotezi Çerçevesinde Test Edilmesi. (Discussion Paper of Turkish Economic Association 2008/1). Retrieved from (http://www.tek.org.tr).

Aw, B.Y., Chung, S., \& Roberts, M. J. (1998). Productivity andthedecisiontoexport: microevidencefromTaiwan and South Korea. (NBER Working paper no. 6558). Cambridge, MA: NationalBureau of Economic Research.

Baldwin, J.R., \& Johnson, J. (1996), Business Strategies in More and Less-Innovative Firms in Canada. Research Policy, 25(5), 785-804.

Baptista, R., \& Karaòz, M. (2006). Turbulence in Entry and Exit Along the Product Life Cycle. The HEWPEM Conference, Patras, Greece.

Barney, J. (1995). Looking Inside for Competitive Advantage. Academy of Management Executive, 9, 49-61.

Bayyurt, N., \& Duzu, G. (2008). Performance Measurement of Turkish and Chinese Manufacturing Firms: A Comperative Analysis. Eurasian Journal of Business and Economics, 1(2), 71-83.

Becheikh, N., Landry, R., \& Amara, N. (2006). Lessons from Innovation Empirical Studies in the Manufacturing Sector: A Systematic Review of the Literature from 1993-2003" Technovation, 26, 644-664. http://dx.doi.org/10.1016/j.technovation.2005.06.016

Beck, T., Demirguc-Kunt, A., \& Maksimovich, V. (2005). Financial and Legal Constraints to Growth: Does Firm Size Matter? Journal of Finance, 60(1), 137-177.

Bernard, A. B., \& Jensen, J.B. (1999). Exceptional Exporter Performance: Cause, Effect, orBoth? Journal of International Economics, 47(1), 1-25.

Brüderl, J., Preisendörfen, P. \& Ziegler, R. (1992). Survival Chances of Newly Founded Business Organizations. American Sociological Review, 57, 227-242.

Cainelli, G., Evangelista, R., \& Savona, M. (2006). Innovation and Economic Performance in Services: A Firm-Level Analysis. Cambridge Journal of Economics, 30, 435-458.

Carden, S.D. (2005). What Global Executives Think About Growth and Risk. McKinsey Quarterly, 2, 16-25.

Caves, R.E. (2006). Survivor: The Role of Innovation in Firms' Survival. Research Policy, 35, 
626-641.

Chetty, S.K. (1999). Dimensions of Internationalization of Manufacturing Firms in the Apparel Industry. European Journal of Marketing, 33(1/2), 121-142.

Clerides, S.K., Lach, S., Tybout, J.R. (1998). Is learning by exporting important? Microdynamic evidence from Colombia, Mexico, and Morocco. Quarterly Journal of Economics CXIII, 903-947.

Coad. A. (2009). The Growth of Firms. UK: Edward Elgar Publishing Limited.

Cragg, J. (1971). Some Statistical Modelsfor Limited Dependent Variables with Application to the Demand for Durable Goods. Econometrica, 39, .829-844.

Cockburn, I., \& GRILICHES, Z. (1988). Industry Effects and Appropriability Measures in The Stock Market's Valuation of R\&D and Patents. American Economic Review, 78(2), 419-423.

Covin, J.G., \& Slevin, D.P. (1991). A Conceptual Model of Entrepreneurship as Firm Behavior. Entrepreneurship Theory and Practice, 16, 7-24.

Çavuşgil, S.T., \& Naor, J. (1987). Firmand Management Characteristics as Discriminators of Export Marketing Activity. Journal of Business Research, 13(3), 221-235.

Das, S. (1995). Size, Age and Firm Growth in an Inflant Industry: TheComputer Hardware Industry in India. International Journal of Industrial Organization, 13(1), 111-126.

Deeds, D.L. (2001). The Role of R\&D Intensity, Technical Development and Absorptive Capacity in Creating Entrepreneurial Wealth in High-Tech Start-Up. Journal of Engineering and Technology Management, 18, 29-47.

Demirgil H. (2008). Firmaların Hayatta Kalma and Büyüme Performanslarını Belirleyen Faktörler: Göller Bölgesi Üzerine Bir Araştırma (Unpublished doctoral thesis). Social Science Institute of Suleyman Demirel University, Isparta, Turkey.

Dunne, T., Roberts, M.J., \& Samuelson, L. (1988). Patterns of Firm Entry and Exit in U.S. Manufacturing Industries. RAND Journal of Economics, 19(4), 495-515.

Evans \& David S. (1987). The Relationship between Firm Growth, Size, and Age: Estimatesfor 100 Manufacturing Industries. The Journal of Industrial Economics 35(4), 567-581. http://dx.doi.org/10.2307/2098588

Freel, M.S., \& Robson, P.J.A. (2004). Small Firm Innovation, Growth and Performance: Evidence from Scotland and Northern England. International Small Business Journal, 22(6), 561-575.

Geroski, P.A., \& Gugler, K. (2004). Corporate Growth Convergence in Europe. Oxford Economic Papers, 56, 597-620.

Greene, W. H. (2003). Econometric Analysis. New Jersey: PrenticeHall.

Greiner, L. (1972). Evolution and Revolution as Organizations Grow. Harvard Business Review, 37-46.

Hall, R. (1993). A Framework Linking Intangible Resources and Capabilities to Sustainable Competitive Advantage. Strategic Management Journal, 14, 607-618.

Hardwick, P., \& Adams, M. (2002). Firm Size and Growth in the United Kingdom Life Insurance Industry. The Journal of Risk and Insurance, 69(4), 577-593.

Hay, M., \& Kamshad, K. (1994). Small Firm Growth: Intentions Implementation and Impediments. Business Strategy Review, 5(3), 49-68.

Heckman, J. (1979). Sample Selection Bias as a Specification Error. Econometrica, 47, 
A Research on the Performance and Characteristics of the Firms in Turkish Manufacturing...

153-161.

Hymer, S., \& Pashigan, P. (1962). Firm size and rate of growth. The Journal of Political Economy, 70(6), $556-569$.

Higson, C., Holly, S., \& Kattuamn P. (2002). The cross-sectional dynamics of the US business cycle: 1950-1999. Journal of Economic Dynamics and Control, 26(9-10), 1539-55. http://dx.doi.org/10.1016/S0165-1889(01)00084-7

Huynh, K.P., \& Petrunia, R.J. (2009). Age Effects, LeverageAndFirmGrowth. (Working Paper Indiana University).

Jantunen, A. (2005). Knowledge-Processing Capabilities and Innovative Performance: An Empirical Study. European Journal of Innovation Management, 8(3), 336-349.

Karaòz, M. \& Albeni, M. (2011). İ̧ Kuluçkalarında Yeni Kurulan Girişimlerin Hayatta Kalma and Büyüme Performansını Etkileyen Faktörler: KOSGEB iş Geliştirme Merkezleri (işGEM) Üzerine Bir Araştırma (TÜBITAK Project Report). Isparta.

Katsikeas, C.S., Piercy, N.F., \& loannidis, C. (1996). Determinants of Export Performance in a EuropeanContext. European Journal of Marketing, 30(6), 6-35.

Kồmùrcù, E. (2008). İmalat Sanayiinde İş Mükemmelliğinin Firma Performansına Etkilerinin Araştırılması (Unpublished master thesis). Sabancı Üniversitesi, Turkey.

Mata, J., Portugal, P., \& Guimares, P. (1995). The Survival of New Plants: Start-up Conditionsand Post-EntryEvolution. International Journal of Industrial Organization, 13, $459-481$.

Mcpherson, M.A. (1996). Growth of Micro and Small Enterprises in Southern Africa. Journal of Development Economics, 48, 253-277. http://dx.doi.org/10.1016/0304-3878(95)00027-5

Mishra, P., \& Chandra, T. (2010). Mergers Acquisitons and Firm's Performance: Experience of Indian Pharmaceutical Industry. Eurasian Journal of Business and Economics, 3(5), 111-126.

Niskanen, M., \& Niskanen J. (2005). The determinant of Firm Growth in Small and Micro Firms-Evidence on Relationship Lemding Effects. School of Business and Administration, University of Kuopio, Finland.

O'Cass, A., \& Craig, J. (2003). Examining Firm and Environmental Infuences on Export Marketing Mix Strategy and Export Performance of Australian Exporters. European Journal of Marketing, 37(3/4), 366-384.

Penrose, E.T. (1959). The Theory of the Growth of the Firm. Oxford: Basil Blackwell.

Robson, P., \& Bennett, R. (2000). SME Growth: The Relationship with Business Advice and External Collaboration. Small Business Economics, 15(3), 193-208.

Rothaermel, F.T., \& Thursby, M. (2005). Incubator Firm Failure or Graduation? The Role of University Linkages. Research Policy, 34, 1076-1090.

Segarra, A., \& Callejon, M. (2002). New Firm Survival and Market Turbulence: New Evidence from Spain. Review of Industrial Oranization, 20, 1-14. http://dx.doi.org/10.1023/A:1013309928700

Shanmugam, K.R., \& Bhaduri, S.N. (2002). Size, Age and Firm Growth in the Indian Manufacturing Sector. Applied Economics Letters, 9(9), 607-613.

Seleim, A., \& Ashour, A., \& Bontis, N. (2004). Intellectual Capital in Egyptian Software Firms. The Learning Organization, 11(4/5), 332-346.

Sougiannis, T. (1994). The Accounting-based Valuation of Corporate R\&D. The Accounting 
Review, 69, 44-68.

Stewart, T.A. (1994). Your Company's Most Valuable Asset: Intellectual Capital. Fortune, 3, 68-74.

Stinchcombe, A. L. (1965). Social Structure and Organizations. In J.G. March (Ed.), Handbook of Organizations (pp.142-193). Chicago, IL: RandMcNally \& Company.

Taticchi, P., Kashi, R., Balachandran, M., \& Cagnazzo, B.L. (2008). Performance Measurement Management for Small and Medium Enterprises: An Integrated Approach. Journal of Applied Management Accounting Research, 5(2), 57-72.

Tobin, J. (1958). Estimation of Relationship for Limited Dependent Variables. Econometrica Journal of the Econometric Society, 26(1), 24-36

TÜik. (2013). Turkey's Statistical Yearbook 2012, Ankara: Turkish Statistical Institute.

TÜsiAD. (2008). Turkish Industry: A Sectoral Overwview. (05/466 Ed.). İstanbul: Turkish Industry and Business Association.

Wang, W., \& Chang, W. (2005). Intellectual Capital and Performance in Causal Models: Evidence from the Information Technology Industry in Tawain. Journal of Intellectual Capital, 6(2), 222-236.

Wagner, J. (2002). The Casual Effects of Exports on Firms Size and Labor Productivity: First Evidence from a Matching Approach. Economic Letters, 77(2), 287-292

Wagner, J. (1992). Firm Size, Firm Growth, and Persistence of Chance. Testing Gibrat's Law with Establishment Data from Lower Saxony, 1978- 1989. Small Business Economics, 4(2), 125-131.

Wiklund, J., \& Shepherd, D. (2003). Knowledge-based Resources, Entrepreneurial Orientation, and the Performance of Small and Medium Sized Business. Strategic Management Journal, 24, 1307-1314.

Ulusoy, G., Alpkan, L., Kiliç, K., \& Öner, M.A. (2008). Imalat Sanayiinde Inovasyon Modelleri ve Uygulamaları Projesi Raporu (Tubitak Project, Sobag -No: 105K105). İstanbul.

Yasuda, T. (2005). Firm Growth, Size, Age and Behavior in Japanese Manufacturing. Small Business Economics, 24, 1-15. http://dx.doi.org/10.1007/s11187-005-7568-y

Yücel, A. (2006). İhracat Pazarlaması Stratejilerinin Firma Performansı Üzerine Etkileri Hazır Giyim Firmaları Üzerine Bir Uygulama (Unpublished doctoral dissertation). Social Science Institute of Ankara University, Ankara, Turkey. 